\title{
FACTORS AFFECTING RELATIVE EFFICIENCY OF HIGHER EDUCATION INSTITUTIONS OF ECONOMIC ORIENTATION*
}

\author{
Andrea Arbula Blecich **
}

Received: 2. 3. 2019

Original scientific paper

Accepted: 6. 5. 2020

UDC 005.336.1:378

DOI https://doi.org/10.30924/mjcmi.25.1.3

$378: 33(497.4 / .6)$

\begin{abstract}
This paper investigates the factors that influence the relative efficiency of higher education institutions of economic orientation. The empirical analysis is carried out on 31 higher educational institutions of economic orientation in Croatia, Slovenia and Bosnia and Herzegovina, in three phases. In the first phase, relative efficiency of observed institutions is evaluated for three main areas of their activities: teaching, research and international activity. In the second phase, higher education institutions are clustered based on relative efficiency results of each individual area of their activity. In the last, third phase, key association factors of a particular cluster are determined using univariate binary logistic regression and odds for transition to a more favourable cluster are defined. The results indicate that odds for positioning in the more efficient cluster are higher in public institutions than in private ones, in institutions with more published professional papers, in those with higher expenditures per faculty, the larger number of enrolled students per faculty, as well as in those with more visiting researchers. The proposed model can serve as a design guideline for education policies and as a moderation guideline for national authorities.
\end{abstract}

Key words: efficiency, higher education institutions, data envelopment analysis, cluster analysis, logistic regression

\section{INTRODUCTION}

Education is a strategic area of interest in every country because the quality of the human capital heavily affects the economic development (Kruss, McGrath, 2015; Neamtu, 2015). According to the findings of the national audit of 2011, the Croatian universities are inefficiently organized and are using the available resources ineffectively (Ministry of science and education of the Republic of Croatia, 2012). This is one of the reasons to conduct a detailed study of the relative efficiency of higher education institutions (HEIs) in Croatia and other countries of Southeast Europe. Accordingly, the goal of this research is to identify and quantify the factors influencing the relative efficiency of HEI of economic orientation, aiming to enhance their performance. Beside the HEI of economic orientation in Croatia, this analysis also includes institutions of similar profile from Slovenia and Bosnia and Herzegovina. These three countries were part of the former Yugoslavia and consequently have inherited and developed similar education systems. After the breakup of Yugoslavia

\footnotetext{
* This work has been fully supported by/supported in part by the University of Rijeka under the project number [uniri-drustv-18-166].

** Andrea Arbula Blecich, PhD, Assistant professor, University of Rijeka, Faculty of Economics and Business, Ivana Filipovića 4, 51000 Rijeka, Croatia, Tel: +385 51355 117, E-mail: andrea.arbula.blecich@efri.hr
} 


\section{Journal of Contemporary Management Issues}

in 1991 and the declaration of independence in Croatia and in Slovenia, Bosnia and Herzegovina became independent in 1992. After the Bologna declaration in 1999, the HEIs of Croatia, Slovenia and Bosnia and Herzegovina gradually transformed their study programmes according to the Bologna Process. In these countries, higher education is organized binary, meaning that there are firstly university studies, which are further subdivided into undergraduate (180-240 ECTS), graduate (60-120 ECTS) and postgraduate studies. Secondly, there are professional studies, which are subdivided into undergraduate (120-180 ECTS) and graduate studies (60-120 ECTS). Certain professions have integrated undergraduate and graduate university studies (300-360 ECTS). In Croatia, Slovenia and Bosnia and Herzegovina between $12 \%$ and $17 \%$ of the total number of students are pursuing degrees in the field of economics (Agency for science and higher education in Croatia, 2014; Republic of Slovenia - statistical office, 2012-2014; Institute for statistics of Federation of Bosnia and Herzegovina, 2012-2014). This supports the fact that HEIs of economic orientation are the most numerous among HEIs and there is a strong competition between them in attracting students. In the observed countries, higher education is traditionally mostly funded by public sources. The economic crisis has pushed countries to obtain the best possible outputs from available resources. It is therefore necessary to measure the efficiency of the public sector. Over the years, various evaluation methods of higher education have been developed. In the private sector, this process is easier than in the public sector because there the most important evaluation criteria is level of profit. On the other hand, since the function of the public sector is satisfying public needs, outputs are often qualitative in nature, which makes them more difficult to measure.

\section{LITERATURE REVIEW}

Evaluation of the relative efficiency of higher education has been in the focus of numerous researches worldwide. Most studies were conducted in the United Kingdom (UK) and the United States (US). The early phase of research into relative efficiency in higher education is considered to start in the middle of the 1970s (Brovender, 1974; Tierney, 1980; Verry and Layard, 1975). These researches are specific because only one output was used. This proved to be problematic because HEIs produce many different outputs. One of the first authors who addressed this problem is James (1978). His research attempted to separate the costs of undergraduate studies, graduate studies and research at the university. It is noticed that if only one output is taken, in the case of undergraduate students, while ignoring other outputs, the cost of undergraduate education becomes overestimated. One of the first efficiency studies where HEIs are considered as organizations that produce multiple outputs is that of Cohn, Rhine and Santos (1989). It was conducted in 1987 on public and private HEIs in the US. Their cost function consists of three outputs (students included in the undergraduate education, students included in the graduate education and scholarships for research) and one input (average college salary). Results showed that in both, public and private HEIs, economy of scale has a significant impact. Robst (2001) analysed whether the change in the structure of US HEIs revenue influenced their relative efficiency. He concluded that in most institutions the share of government revenue decreased. Those HEIs with smaller reduction in government revenue share proved to be more efficient than those whose revenue share declined significantly. In Europe, most studies on the relative efficiency of HEIs is being conducted in the UK. Thanassoulis et 
al. (2011) underlined the importance of the UK government to understand the cost structure of higher education. Authors used data envelopment analysis (DEA) to assess the cost structure and to determine the effect of various groups of HEIs in England. They compared unit costs of each observed subject obtained with DEA with those obtained by parametric estimates and concluded that they are very similar. Additionally, research results showed significant space to increase number of students at no additional cost where there is the largest space for advancement. Beasley $(1990,1995)$ also studied relative efficiency of UK universities and was the first one who identified the problem of basic DEA models assumption where all outputs of decision making units (DMU) are result of a single production process. Therefore, it is suggested to evaluate separately efficiency of processes of teaching and research. Mar Molinero (1996) and Tsai and Mar Molinero (2002) continued Beasley's research and proposed a modified DEA model that would allow implementation of his idea. Murias, de Miguel and Rodríguez (2008) measured the quality of Spanish universities and created a synthetic indicator for quality measurement.

Recent studies of efficiency in higher education use DEA as a first stage analysis. In a second stage, external factors that affect efficiency of HEI are investigated using mostly tobit regression. WolszczakDerlacz (2017) studied technical efficiency on number of public European and American HEIs as well as external factors that affect obtained efficiency. HEI's efficiency is positively associated with both, regional GDP per capita and number of HEI's departments for both, European and U.S. HEIs. Age of an institution and government funding are confirmed to be significant only for European HEIs. Older institutions are on average more efficient as well as institutions that receive less government funding. Wolszczak-Derlacz and Parteka (2011) carried out a two-stage analysis on a set of 259 universities in seven European countries for the period 2001-2005. They found that higher number of different departments among university, a larger percentage of females among academic staff, a higher proportion of funds from external sources and more years since HEI establishment have positive effect on efficiency of university. Agasisti (2011) conducted two-stage analysis of HEI efficiency on 18 OECD countries. Efficiency of higher education systems is positively affected by the GDP per capita and negatively by share of public funding on tertiary education. Sibel and Bursalioglu (2013) used DEA and tobit regression to determine factors that affect efficiency of 51 public universities in Turkey in the period 2006-2010. Research results indicate positive effect of number of students per academic, employment and number of publications, and negative effect of central government budget appropriations on relative efficiency of Turkish universities.

Although in Croatia the evaluation of HEIs is still a relatively new field of research, recently there has been an increase in scientific interest on this topic. One of the earlier evaluation studies of the higher education in Croatia is that of Jakir - Bajo (2003) where the reasons for evaluation of performance in the public sector are outlined as well as the measurement frame. Analysis of the performance of HEIs in Croatia was conducted by Ćukušić, Garača and Jadric (2014) with the aim to establish guidelines and performance indicators of HEIs. Cerović, Arbula Blecich and Štambuk (2014) proposed a model for evaluating the quality of faculties of economic orientation by defining the areas of quality evaluation using the method of the 


\section{Journal of Contemporary Management Issues}

aggregate index. A mathematical model was based on assigned corresponding weights obtained from experts' opinions in certain areas of quality. Arbula Blecich and Zaninović (2019) analysed students' perception of teaching from the perspective of students' interest, teacher and course assessment. They used ordinal logistic model to quantify the effects of grade, pass rate and class size on evaluations results of undergraduate and graduate courses. Evaluation of the relative efficiency of government spending on higher education in selected EU countries with regard to Croatia was conducted by Arbula (2012) and Aristovnik and Obadić (2011). These studies have confirmed low level of relative efficiency of higher education in Croatia compared to other European countries. Aristovnik (2012) measured relative efficiency in utilizing public education (including tertiary education) and R\&D expenditures in selected EU and OECD countries including Croatia. The research results suggested that, in general, emerging market economies in the EU and OECD regions are relatively less efficient, particularly in $\mathrm{R} \& \mathrm{D}$ sector.

\section{METHODOLOGY}

This study uses three different methods to identify key factors associated with positioning in a particular cluster. Each of these methods represents one phase of the analysis and they are: data envelopment analysis (DEA), cluster analysis and univariate binary logistic regression. Results from the previous phase are inputs for the following one.

\subsection{Data envelopment analysis}

DEA is a mathematical non-parametric method developed by Charnes, Cooper and Rhodes (1978) and used for evaluation of relative efficiency of a set of decision making units (DMUs) by calculating the ratio between weighted inputs and weighted outputs for every single DMU. DMUs that achieve optimal value $\theta=1(100 \%$ relative efficiency) are considered to be relatively efficient, where $\theta$ indicates the level of efficiency). DMUs that have result of efficiency less than one are considered to be relatively inefficient $(0 \leq \theta<1)$. Relatively efficient DMU is the one that cannot reduce any input, without reducing any of the outputs or increasing any of the remaining inputs. Likewise, relatively efficient DMU is also one that cannot increase any output, without increasing any of their inputs or reducing any of the remaining outputs. Relative efficiency implies comparison of DMUs in a way that those relatively inefficient are compared with those relatively efficient. Charnes, Cooper and Rhodes (1978) enabled calculation of the results of relative efficiency for each DMU and established DEA as we know it today. The original model that they presented assumed input orientation and constant returns to scale (CRS). CRS implies that an increase of each input of every DMU causes the proportional increase of each output. The methodology was upgraded by Banker, Charnes and Cooper (BCC) (1984) who proposed variable returns to scale (VRS). VRS implies that increase of each input of every DMU does not necessarily cause the proportional increase of each output. DEA models can have input or output orientation that depends on the goals of the specific DMU whose efficiency is evaluated.

This method was originally developed for evaluation in public sector, but soon it expanded also into the non-public sector where other methods did not give satisfactory results. Today, DEA is used in healthcare (Dukić Samaržija, Arbula Blecich and Najdek, 2018; Khushalani and Ozcan, 
2017), education (Sîrbu, Cimpoieş and Racul, 2016; Thanassoulis et al., 2011) and other areas. DEA has advantages over other methods because it can easily accommodate multiple inputs and multiple outputs expressed in different units. Additionally, inefficient DMUs have real role models, but it is not known how much the relative efficiency differs from the absolute one. Main limitation of DEA is potential sensitivity of efficiency results on the inputs and outputs selection. Number of efficient DMUs tends to increase with including more input and output variables. These limitations can be overcome by including only fundamental inputs and outputs in the analysis. DEA is also sensitive on sample size which means that average efficiency score will reduce when sample size increase. In addition, since DEA measures relative efficiency within the particular sample, comparison of results between different studies is not meaningful. With a mindful approach many limitations can be overcome.

\subsection{Cluster analysis}

Cluster analysis is a multivariate statistical method used for identification of homogeneous groups (clusters) where the group affiliation of the observed object and the number of groups are not known (Mooi and Sarstedt, 2011). Different objects are connected in the clusters based on the distance matrix that determines the links between them. Objects can be individuals, companies, institutions, etc. In this paper objects are 31 HEIs of economic orientation (DMUs). After defining the objects, variables (characteristics of objects) are selected. Based on their similarities and differences the sample will be divided into clusters. When selecting variables, it is important that their selection is based on the purpose of the analysis. The next step is selection of distance measure or measure of similarity. There are several methods for calculating the distance and similarity (correlation) between the vectors $x=\left(x_{1}, x_{2}, \ldots\right.$ $\left.x_{p}\right)$ and $y=\left(y_{1}, y_{2}, \ldots y_{p}\right)$. Most common distance measure for interval data is Euclidean distance:

$d(x, y)=\sqrt{\sum\left(x_{i}-y_{i}\right)^{2}}$

In addition to the selection of distance measure, it is important to choose the appropriate method for clusters formation. In this paper hierarchical agglomerative method is used. The starting point in this method are the individual objects as initial clusters. With each following step two closest clusters connect. This process continues until it reaches the stop criteria (Kaufman and Rousseeuw, 1990, 2005). In the paper Ward's method is used. First, the mean for each variable of each cluster is calculated. Then the squared Euclidean distance to the arithmetic mean of clusters is calculated for each object after which the distances sum up for all cluster members. Clusters are formed in a way that clusters, for which the overall sum of the deviation is smallest, merge. Output of cluster analysis can be displayed as a dendrogram.

\subsection{Logistic regression}

Logistic regression is a type of regression analysis that models the relationship between the dichotomous dependent variable (criterion), $y$, and one or more independent variables (predictors), $x$, based on an assessment of probability. It is a method that forecasts the probability of various possible outcomes of the categorical dependent variable based on a set of independent variables. It is used when the relationship between the dependent variable and independent variables is not linear. In this paper binary logistic regression is used to predict 


\section{Journal of Contemporary Management Issues}

the probability of transition from one cluster to another based on the change of independent variables, $x$. Value 1 is assigned to predictors that are positioned in the higherranked cluster 1 , and value 0 is assigned to predictors positioned in the lower-ranked cluster 2. The logistic function is expressed by equation (Gujarati and Porter, 2009):

$$
y=\frac{1}{1+e^{-k(x-a)}} \text {, where }
$$

$k$ is the slope coefficient of the function, and $a$ is the value on the abscissa at which the $\mathrm{y}=0.5$.

Equation (2.2) is the cumulative distribution of logistic function. The relationship between the dependent variable, $y$, and an independent variable, $x$, is nonlinear. Function has an exponential growth at negative values of $x$, then gradually slows down and moves in a linear growth near $x$ $=0$. For positive values of $x$ the difference between function and $y=1$ exponentially decreases. Function $y$ (2.2) represents the probability of existence of a particular outcome. The probability of absence of the same outcome can be defined as $1-y$. The ratio between the probability of existence of outcome and the probability of absence of the same outcome represents the odds ratio, $y /(1-y)$ (Gujarati and Porter, 2009):

$\frac{y}{1-y}=\frac{1+e^{x}}{1+e^{-x}}=e^{x}$

The result of the natural logarithm of the odds ratio is the independent variable, $x$, i.e. (Gujarati and Porter, 2009):

$$
L=\ln \left(\frac{y}{1-y}\right)=x
$$

The value $L$ is called logit. Logit is linear both in the independent variables and in the parameters (Gujarati and Porter, 2009). The odds ratio can take values between 0 and $+\infty$. The main disadvantage of the binary logistic regression is a need for a larger sample for each predictor than in the linear regression. Peduzzi et al. (1996) defined the calculation of the minimum number of parameters by variables:

$$
N=\frac{10 k}{p} \text {, where }
$$

$k$ is the number of independent variables and $p$ is the smaller proportion of positive or negative dependent variable. In the case of the model presented in the article, if one independent variable is used, given that the number of DMU grouped in the unfavourable group 2 is equal to 11 (out of 31 ), a sample of at least 28 DMUs is required. If the analysis included two independent variables, the minimum required sample in the model should consist of at least 56 DMUs. Therefore, in this paper, with respect to the sample of 31 DMUs, univariate binary logistic regression is used.

\section{EMPIRICAL MODEL}

\subsection{The model assumptions}

The assumptions of the model are based on two basic issues. The first issue is the definition of relevant areas of HEIs of economic orientation, while the second issue is related to the selection of relevant inputs and outputs of each area of activity. In previous studies, efficiency evaluation was conducted in a way that the combination of inputs and outputs resulted in a single grade based on which the DMUs are ranked (Badri, Mohaidat and El Mourad, 
2014; Liu and Tsai, 2014). Certain studies of relative efficiency of HEIs differ outputs related to the teaching and outputs related to the research (Sagarra, Agasisti and Mar Molinero, 2017). The proposed model assumes that HEIs are not equally efficient in all areas of their activities. Therefore, instead of a single grade, efficiency of each area of activity should be evaluated separately. That would allow HEIs to make targeted adjustments in the inefficient areas. The empirical model is tested on 31 HEIs of economic orientation in three European countries: Croatia, Slovenia and Bosnia and Herzegovina. The empirical analysis was performed following three phases. In the first phase, DEA is used to test four models. Three models evaluate relative efficiency of teaching, research and international activity of observed institutions, while relative efficiency of overall activity is evaluated with the fourth model. Based on the efficiency results of main areas of activity, in the second phase, HEIs are grouped into two clusters. In the last, third phase, key association factors of a particular cluster are determined by using univariate binary logistic regression and probability of transition to a more favourable cluster is defined. The peculiarity of this model in relation to standard models is that it provides different point of view as it offers both a comprehensive and a general insight into identifying key factors for positioning in a specific cluster. The model is shown in the figure below.

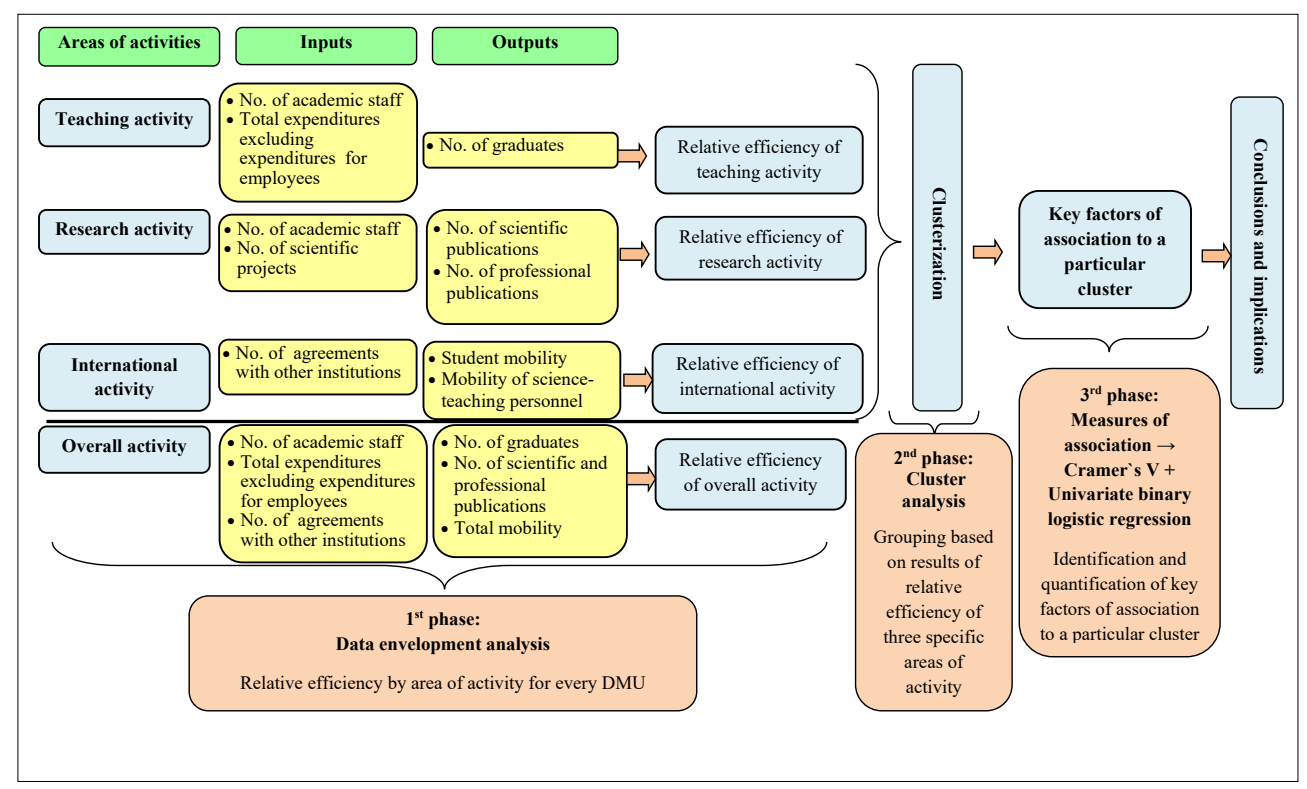

Figure 1: Empirical model for the evaluation of efficiency of higher education institutions of economic orientation

Source: Author

\subsection{Sample selection}

The main requirement for sample selection is that HEI provides a degree in social sciences, field of economy (undergraduate level or more). The analysis includes private and public HEIs of economic orientation from the following affiliation: faculties, university departments, departments of polytechnics and private colleges that are 


\section{Journal of Contemporary Management Issues}

at the same level in European qualification framework (EQF), Croatian qualifications framework (CQF), Slovenian qualifications framework (SQF), and qualification framework in Bosnia and Herzegovina (QFBIH). Croatia has 31, Slovenia 10 and Bosnia and Herzegovina 21 HEIs that meet these requirements. The paper evaluates 21 HEIs in Croatia ( $71 \%$ of total population), 7 HEIs in Slovenia ( $70 \%$ of total population) and 2 HEIs in Bosnia and Herzegovina (9.5\% of total population). Criteria for selection of the relevant areas of activity of HEIs of economic orientation arise from the Bologna declaration and the European Standards and Guidelines for Quality Assurance (ESG).

\section{TESTING OF THE EMPIRICAL MODEL AND EMPIRICAL RESULTS}

\subsection{First stage: Evaluation of relative efficiency of $\mathrm{HEIs}$ of economic orientation using DEA}

\subsubsection{Selection of inputs and outputs}

Selection of inputs and outputs is a complex process in evaluation of the relative efficiency using DEA. It is necessary to select relevant inputs and outputs that will provide the most complete information about the relative efficiency of individual DMUs. Evaluation of relative efficiency of HEIs of economic education is carried out in three different areas of activities (teaching activity, scientific and professional activity and international activity). Within each area, based on literature and data availability, specific inputs and outputs are identified. When defining variables, care must be taken to the direction and height of correlations between inputs and outputs that must be positive. Pearson correlation test is used to determine the height and direction of the correlations between variables. Values greater than 0.8 represent a high correlation, while values below 0.4 represent low correlation (Adler and Yazhemsky, nd). If there is a high correlation between a single input and other input(s) i.e. one output and other output(s), it is assumed that input/ output explains the correlated variables and it can be excluded from the analysis. If, on the other hand, input has a very low correlation with the output(s) and vice versa, variable is not suitable for the model (Yang, 2009; Sarkis, 2002). When defining inputs and outputs, it is important that the number of DMUs must be at least 3 times greater than the sum of inputs and outputs. After the insight into correlations and expulsion of highly correlated variables within inputs and outputs and too low correlated variables from the input-output, and vice versa, following inputs and outputs are identified for each area of the institution:

Teaching activity (TA) is considered to be the primary activity of HEIs and as such is most often being the subject of evaluation. The efficiency of teaching activity refers to the teaching with the aim of providing knowledge at undergraduate and graduate levels. The most important stakeholders of the teaching process are teachers and students. This area is subject to internal quality assurance in HEIs according to the ESG. In this research relative efficiency of DMUs in this area is defined by the following variables:

- Inputs:

- Number of academic staff (ACSTUFF) - one of the most important inputs of teaching and as such highly represented in the literature (Abd Aziz Mohd Janor and Mahadi, 2013; Johnes, 2006). This measure takes into account all the 
Management, Vol. 25, 2020, No.1, pp. 45-67

A. A. Blecich: FACTORS AFFECTING RELATIVE EFFICIENCY OF HIGHER EDUCATION ...

teachers involved in the teaching process (Abbott and Doucauliagos 2003; Liu and Tsai, 2014).

- Total expenses excluding expenses for employees (EXPE) - As "expenses for employees" are highly correlated with the "number of academic stuff" and since the operating expenses are an important factor for performance of the core business of HEIs, the input "expenses excluding expenses for employees" is selected (Abbott and Doucauliagos, 2003; McMillan and Datta, 1998). This variable is expressed in Croatian currency, HRK.

- Outputs:

- Number of graduates (GRAD) This variable is a typical output of higher education (Abd Aziz Mohd Janor and Mahadi, 2013; Sagarra, Agasisti and Mar Molinero, 2017). It includes students who graduated at undergraduate and graduate levels.

Research activity (RA) is, besides, teaching activity considered to be one of the key areas of activity of HEIs. Although some of DMUs do not prioritise research activity (this refers primarily to private colleges), Agency for science and higher education (ASHE) encourages, in particular, this kind of activities within its re-accreditation procedures:

- Inputs:

- Number of academic staff (ACSTUFF) - This joint input is used for teaching and research activity because the same staff is usually involved in the process of teaching and research.
- Number of scientific projects (SCPROJ) represents a number of national and international scientific projects on HEIs. Scientific and professional publications are associated with scientific projects at the institution. The aim is that the existing projects result in as many scientific and professional publications, which is why this variable is used as an input of research activity.

- Outputs:

- Number of scientific publications (SCPUB) - This variable is the most important output of research activity. (Sagarra, Agasisti and Mar Molinero, 2017; Sîrbu, Cimpoieş, and Racul, 2016). The number of published scientific papers is a requirement for external evaluation of the research activity as well as the condition of progress in the higher scientific and teaching title.

- Number of professional publications (PROPUB) - Since the scientific and technical papers are evaluated separately, these categories are observed apart from each other.

International activity (IA) has become important segment of HEIs business activities. One of the determinants of European policy is creation of joint European Higher Education Area. This includes the free exchange of students, professors, and researchers in the higher education and science (MSES, nd). Promoting mobility is one of the objectives of the Bologna Declaration and the Bologna process which is why the international activity is considered to be one of main areas of HEI activities (Arbula Blecich and Tomas Žiković, 2016). 


\section{Journal of Contemporary Management Issues}

- Input:

- Number of agreements with other institutions (AGREE) - With the signing of the Bologna Declaration and profiling of mobility as one of key determinants of the quality of institutions, HEIs have begun to sign bilateral and multilateral agreements in order to achieve higher mobility. This variable represents the input of international activity because it is considered to be the institutional framework of cooperation of HEIs.

- Outputs:

- $\quad$ Student mobility (STMOB) - Refers to the number of outgoing and incoming students. Number of outgoing students gives information on the efforts of institutions to send students on exchange, while the number of incoming students gives information on the recognisability of institutions. Given the lack of data for all the DMUs as the exact time spent on the exchange, this dimension is not respected.

- Mobility of academic stuff (ACMOB) - This variable represents the number of outgoing and incoming academic staff. Due to limitation of data, the length of stay was not taken as a factor of evaluation.

Overall activity (OA) - this model combines inputs and outputs of specific areas of activities and provides the collective rating of relative efficiency. Set this way, the model does not respect the special areas of activities. When choosing the input and output, due to high correlations, certain variables had to be removed while others had to be modified and as such represent a surrogate measures.
- Inputs:

- Number of academic staff (ACSTUFF)

- Total expenses excluding expenses for employees (EXPE)

- Number of agreements with other institutions (AGREE)

- Outputs:

- Number of graduates (GRAD)

- Mobility (MOB)- Incoming and outgoing students and academic stuff

- Number of scientific and professional publications (SCPROPUB) Total number of scientific and professional publications.

The chosen method and model have some limitations. First of all, it is reflected in the fact that results obtained in this way provide information about the relative, not absolute efficiency of the observed DMUs. Therefore, a change in selected DMUs would have an impact on the results. The same applies to the selection of inputs and outputs. Because of the partially aggregated data for some DMUs, the estimation of the financial parameters is carried out based on the number of students as a key of allocation. Unavailability of certain data is a limitation in a choice of inputs and outputs.

\subsubsection{Testing the model of the relative efficiency of HEIs of economic orientation using DEA}

Evaluation of HEIs of economic orientation was conducted on data collected in 2012, i.e. for 2011-2012 academic year. In this analysis, the software package DEA Solver Pro 11.0 is used. Data for inputs and outputs are collected through 
the author's questionnaire, the Croatian Ministry of Finance, the Amadeus database, Fin info portal, reports of the expert committee ASHE on re-accreditation of HEIs, self-evaluation of HEIs, the strategy of HEIs, the work plan of HEIs, CROSBI database, SICRIS database and official websites of the observed subjects. In order to conduct the model testing, it is important to define two key determinants first. One is the choice of the model (CCR or $\mathrm{BCC}$ ), and the other refers to its orientation (input or output oriented model). Both are defined according to DMUs characteristics. The decision which model to choose depends on the returns to scale of the observed process. If the returns to scale are constant, the CCR model should be used, and if they vary, the BCC model should be used. In order to accurately determine the appropriate model, it is recommended to do the analysis with both models and compare the results. Orientation of the model is chosen based on the goals that observed DMUs want to achieve. Given that HEIs aim to utilize resources at their disposal to produce maximum outputs, the output oriented model is used (Arbula, 2012; Arbula Blecich and Tomas Žiković 2016).

Table 1: Comparison between CCR and BCC output oriented model

\begin{tabular}{lllllll}
\hline & & $\begin{array}{l}\text { Efficient } \\
\text { DMUs }\end{array}$ & $\begin{array}{l}\text { Inefficient } \\
\text { DMUs }\end{array}$ & Average & Max & Min \\
\hline \multirow{2}{*}{ TA } & CCR & 1 & 30 & 0.4244 & 1 & 0.0724 \\
\cline { 2 - 7 } & BCC & 6 & 25 & 0.5958 & 1 & 0.0767 \\
\hline \multirow{2}{*}{ IA } & CCR & 10 & 21 & 0.5599 & 1 & 0.0001 \\
\hline OA & BCC & 11 & 20 & 0.5788 & 1 & 0.0001 \\
\hline & BCR & 2 & 29 & 0.2847 & 1 & 0.0001 \\
\hline
\end{tabular}

Source: Author's calculations

Comparing the results of relative efficiency for 31 HEIs of economic orientation using output oriented CCR and BCC models, a significant difference in the number of efficient $(\theta *=1)$ DMUs for teaching activities, international activities and overall activities has been observed, which is why in this areas of activities the BCC model is used. In the area of research activity, the deviation is minimal (CCR model identifies 10 and $\mathrm{BCC} 11$ relatively efficient DMUs) and the CCR model is used. The values obtained indicate a high inconsistency in results among different areas of activity. The highest average score is recorded for overall activity, which explains that the HEIs, on average, are not equally efficient in every area of activity. They substitute relatively efficient results in one area of activity with relatively less efficient results in other areas of activity. Therefore, the evaluation of the individual areas of activity is justified because it gives more accurate picture of the HEIs operations. The table below shows individual results of relative efficiency in each individual area for each DMU. 
Journal of Contemporary Management Issues

Table 2: Relative efficiency obtained by data envelopment analysis for different areas of activity

\begin{tabular}{|c|c|c|c|c|c|c|c|c|}
\hline DMU & $\mathrm{TA}-\mathrm{BCC}$ & Rank & $\mathrm{RA}-\mathrm{CCR}$ & Rank & IA - BCC & Rank & $\mathrm{OA}-\mathrm{BCC}$ & Rank \\
\hline DMU1 & 0.9154 & 11 & 0.452 & 16 & 0.2534 & 20 & 1 & 1 \\
\hline DMU2 & 1 & 1 & 0.4677 & 15 & 0.1976 & 22 & 1 & 1 \\
\hline DMU3 & 0.4322 & 19 & 0.5469 & 14 & 0.3321 & 18 & 0.7746 & 18 \\
\hline DMU4 & 1 & 1 & 0.6523 & 12 & 0.8148 & 7 & 1 & 1 \\
\hline DMU5 & 0.9469 & 10 & 0.3248 & 23 & 0.1893 & 23 & 1 & 1 \\
\hline DMU6 & 0.2262 & 25 & 1 & 1 & 0.1845 & 24 & 0.3767 & 29 \\
\hline DMU7 & 0.0767 & 31 & 0.3557 & 21 & 0.1023 & 27 & 0.3106 & 31 \\
\hline DMU8 & 0.2204 & 26 & 0.2393 & 24 & 0.0001 & 31 & 0.4489 & 28 \\
\hline DMU9 & 0.3434 & 22 & 0.2187 & 25 & 0.0824 & 28 & 0.4977 & 27 \\
\hline DMU10 & 0.3328 & 23 & 1 & 1 & 0.392 & 13 & 0.8565 & 16 \\
\hline DMU11 & 0.2103 & 27 & 0.0001 & 30 & 0.269 & 19 & 0.3142 & 30 \\
\hline DMU12 & 0.7067 & 13 & 0.6332 & 13 & 0.6622 & 8 & 1 & 1 \\
\hline DMU13 & 0.4743 & 18 & 0.4516 & 17 & 0.0383 & 29 & 0.5242 & 25 \\
\hline DMU14 & 0.2684 & 24 & 0.0001 & 30 & 0.467 & 12 & 0.6219 & 22 \\
\hline DMU15 & 0.9999 & 7 & 0.1012 & 28 & 1 & 1 & 1 & 1 \\
\hline DMU16 & 1 & 1 & 1 & 1 & 0.3819 & 14 & 1 & 1 \\
\hline DMU17 & 1 & 1 & 1 & 1 & 0.2045 & 21 & 1 & 1 \\
\hline DMU18 & 0.6798 & 14 & 0.8701 & 11 & 0.3777 & 15 & 0.7264 & 20 \\
\hline DMU19 & 1 & 1 & 0.0861 & 29 & 0.0255 & 30 & 1 & 1 \\
\hline DMU20 & 0.996 & 8 & 1 & 1 & 1 & 1 & 1 & 1 \\
\hline DMU21 & 0.5258 & 17 & 0.1918 & 27 & 0.3624 & 16 & 0.5773 & 23 \\
\hline DMU22 & 0.5568 & 16 & 0.1949 & 26 & 0.9073 & 6 & 1 & 1 \\
\hline DMU23 & 0.9591 & 9 & 1 & 1 & 0.4827 & 11 & 1 & 1 \\
\hline DMU24 & 0.3597 & 20 & 1 & 1 & 0.4868 & 10 & 0.7555 & 19 \\
\hline DMU25 & 0.7943 & 12 & 1 & 1 & 1 & 1 & 1 & 1 \\
\hline DMU26 & 0.1819 & 29 & 0.3616 & 20 & 0.3421 & 17 & 0.5476 & 24 \\
\hline DMU27 & 0.1883 & 28 & 1 & 1 & 1 & 1 & 1 & 1 \\
\hline DMU28 & 0.3449 & 21 & 0.4148 & 19 & 0.1397 & 26 & 0.5219 & 26 \\
\hline DMU29 & 1 & 1 & 1 & 1 & 0.6594 & 9 & 1 & 1 \\
\hline DMU30 & 0.151 & 30 & 0.4412 & 18 & 0.1553 & 25 & 0.6655 & 21 \\
\hline DMU31 & 0.5787 & 15 & 0.3518 & 22 & 1 & 1 & 0.7962 & 17 \\
\hline
\end{tabular}

Source: Author's calculations

According to the observed results of relative efficiency of the individual model for each DMU separately, it is evident that no DMU is relatively efficient in all areas of evaluation $(\exists \theta * \mathrm{i}<1 ; \mathrm{i}=\mathrm{TA}$, RA,
IA). It is also noticeable that some DMUs which are relatively inefficient $(\theta *<1)$ in all areas of activity are evaluated as relatively efficient $(\theta *=1)$ in the overall activity. That is due to the new frontier of 
relative efficiency that is obtained from the new combination of inputs and outputs. These results show a whole new perspective on the evaluation of the relative efficiency of complex DMUs like HEIs. They indicate the importance of evaluation of each area of activity separately in order to obtain more accurate results of relative efficiency for each DMU.

\subsection{Second stage: Grouping of DMUs using cluster analysis}

In the second phase, hierarchical agglomerative cluster analysis is used to classify HEIs into groups according to the achieved levels of relative efficiency in the area of teaching, research and international activity. Euclidean distance is used to measure distances between two vectors $\mathrm{x}=\left(\mathrm{x}_{1}, \mathrm{x}_{2}, \ldots \mathrm{x}_{\mathrm{p}}\right)$ and $\mathrm{y}=\left(\mathrm{y}_{1}, \mathrm{y}_{2}, \ldots \mathrm{y}_{\mathrm{p}}\right)$. The software package Stata/IC 13.0 is used in the analysis. First, the mean of each variable is calculated using Ward's method for each cluster. Then, squared Euclidean distance to the mean of the cluster is calculated for each HEI. These distances are then summed for all cluster members. After that, clusters are formed in a way that clusters for which the total sum of aforementioned deviation is minimal, are connected. The dendrogram shows the process of successive clustering based on similarity of data whereby HEIs (DMUs) are on the $\mathrm{x}$ axis, and distances on the y-axis.

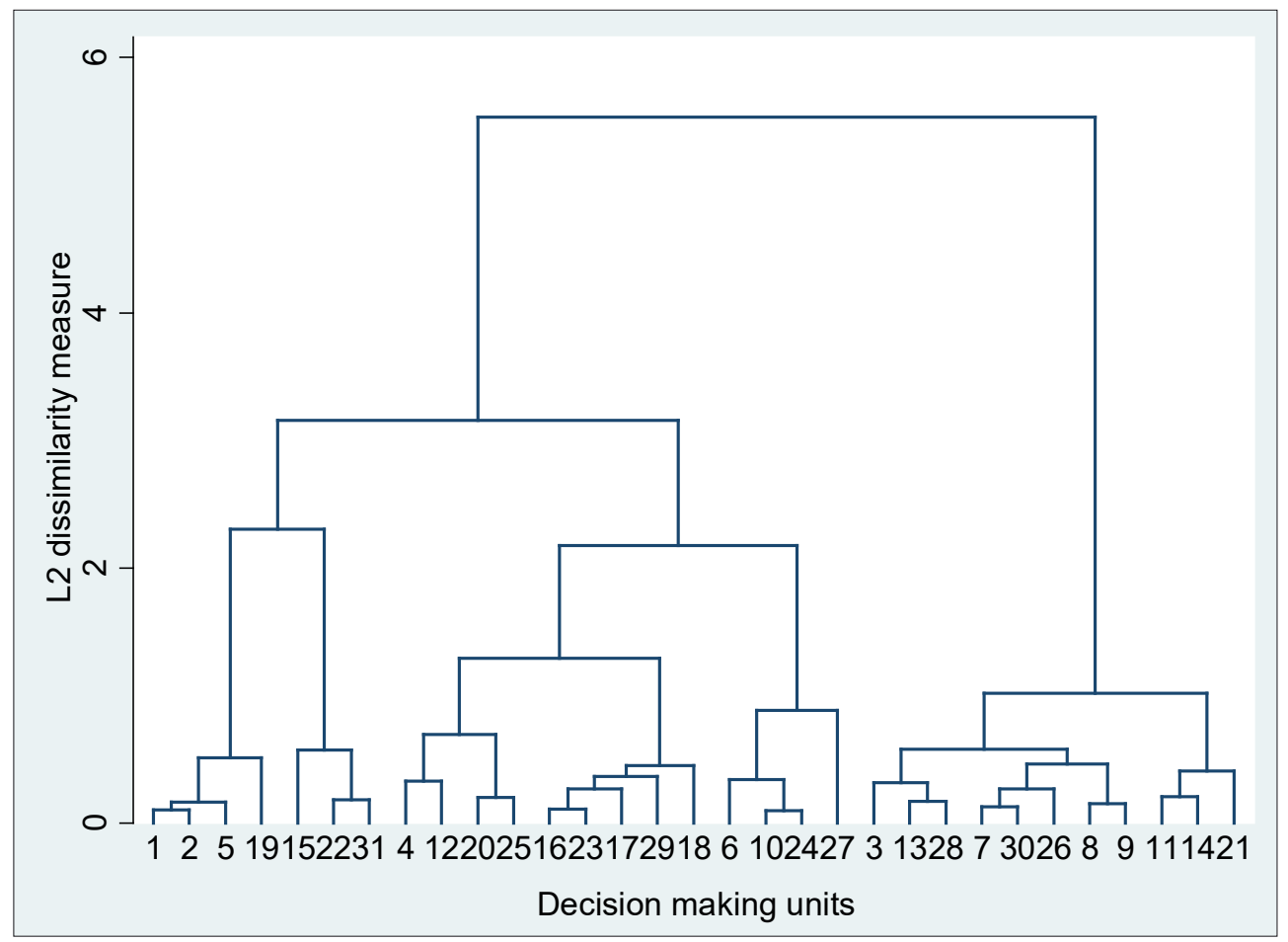

Figure 2: Dendrogram for the cluster analysis

Source: Author 
Two different clusters (groups) are identified. Cluster 1 has 20, and cluster 211 members.

Table 3: DMUs grouped in clusters

\begin{tabular}{llllllll}
\hline DMU & GROUPS & DMU & GROUPS & DMU & GROUPS & DMU & GROUPS \\
\hline DMU1 & $\mathbf{1}$ & DMU9 & $\mathbf{2}$ & DMU17 & $\mathbf{1}$ & DMU25 & $\mathbf{1}$ \\
\hline DMU2 & $\mathbf{1}$ & DMU10 & $\mathbf{1}$ & DMU18 & $\mathbf{1}$ & DMU26 & $\mathbf{2}$ \\
\hline DMU3 & $\mathbf{2}$ & DMU11 & $\mathbf{2}$ & DMU19 & $\mathbf{1}$ & DMU27 & $\mathbf{1}$ \\
\hline DMU4 & $\mathbf{1}$ & DMU12 & $\mathbf{1}$ & DMU20 & $\mathbf{1}$ & DMU28 & $\mathbf{2}$ \\
\hline DMU5 & $\mathbf{1}$ & DMU13 & $\mathbf{2}$ & DMU21 & $\mathbf{2}$ & DMU29 & $\mathbf{1}$ \\
\hline DMU6 & $\mathbf{1}$ & DMU14 & $\mathbf{2}$ & DMU22 & $\mathbf{1}$ & DMU30 & $\mathbf{2}$ \\
\hline DMU7 & $\mathbf{2}$ & DMU15 & $\mathbf{1}$ & DMU23 & $\mathbf{1}$ & DMU31 & $\mathbf{1}$ \\
\hline DMU8 & $\mathbf{2}$ & DMU16 & $\mathbf{1}$ & DMU24 & $\mathbf{1}$ & & \\
\hline
\end{tabular}

Source: Author

Once the clusters are identified, normality of distribution is tested with D'Agostino Pearson test for each variable separately with the aim of selecting the appropriate tests. The values for IA are normally distributed ( $p$ $=0.1052$ ) whereas for the TA and RA they do not follow a normal distribution (TA $\mathrm{p}$ $=0.0002$, and $\mathrm{p}=0.0044 \mathrm{RA})$. In the next step, characteristics of the two groups are observed. Group 1 represents better ranked, while group 2 lower ranked HEIs based on the results of their relative efficiency (Table 4). Since most of the variables do not follow a normal distribution, in the analysis of central tendency the nonparametric MannWhitney test is used to determine whether there are differences in the median between groups. Variable TA has a median value of 0.93115 for the group 1 and a median value of 0.2684 for the group 2, which according to the Mann-Whitney test is a statistically significant difference $(p=0.0003)$. The variable RA has a median value of 0.93505 for the group 1 while for the group 2 it is 0.3557 , which according to the MannWhitney test is a statistically significant difference $(p=0.0033)$. For the variable IA median value is 0.48475 for the group 1 while for the group 2 it is 0.3624 that is according to the Mann-Whitney test a statistically significant difference $(p=0.0029)$. Detailed indicators of descriptive statistics for these variables are presented in the Table 4.

Table 4: Characteristics of clusters and Mann-Whitney test

\begin{tabular}{lllll}
\hline GROUPS & & TA & RA & IA \\
\hline 1 & N & 20 & 20 & 20 \\
& mean & 0.76203 & 0.706705 & 0.56098 \\
& sd & 0.2898838 & 0.3481393 & 0.3398284 \\
& p50 & 0.93115 & 0.93505 & 0.48475 \\
& iqr & 0.43225 & 0.5981 & 0.7247 \\
& N & 11 & 11 & 11 \\
& mean & 0.2935727 & 0.2928909 & 0.2082455 \\
& sd & 0.1427167 & 0.1803555 & 0.1531127 \\
& p50 & 0.2684 & 0.3557 & 0.1553 \\
& iqr & 0.2503 & 0.2494 & 0.2597
\end{tabular}




\begin{tabular}{lllll} 
Total & $\mathrm{N}$ & 31 & 31 & 31 \\
& Mean & 0.5958032 & 0.5598677 & 0.4358161 \\
& Sd & 0.3345496 & 0.3579277 & 0.3322454 \\
& $\mathrm{p} 50$ & 0.5568 & 0.452 & 0.3624 \\
& iqr & 0.7276 & 0.7607 & 0.4777 \\
\hline $\begin{array}{l}\text { Mann-Whitney } \\
\text { Prob }>|\mathrm{z}|\end{array}$ & & 0.0003 & 0.0033 & 0.0029
\end{tabular}

Source: Author's calculations

Based on the results of the MannWhitney test, it is indicative that the cluster analysis confirmed that the position of institutions in a better ranking group (group 1 ) is determined with higher relative efficiency results in all three areas of activity.
In addition, DMUs from the lower ranked group (group 2) achieved lower results of relative efficiency in all three areas of activity. These significant differences are graphically shown in the following figure.

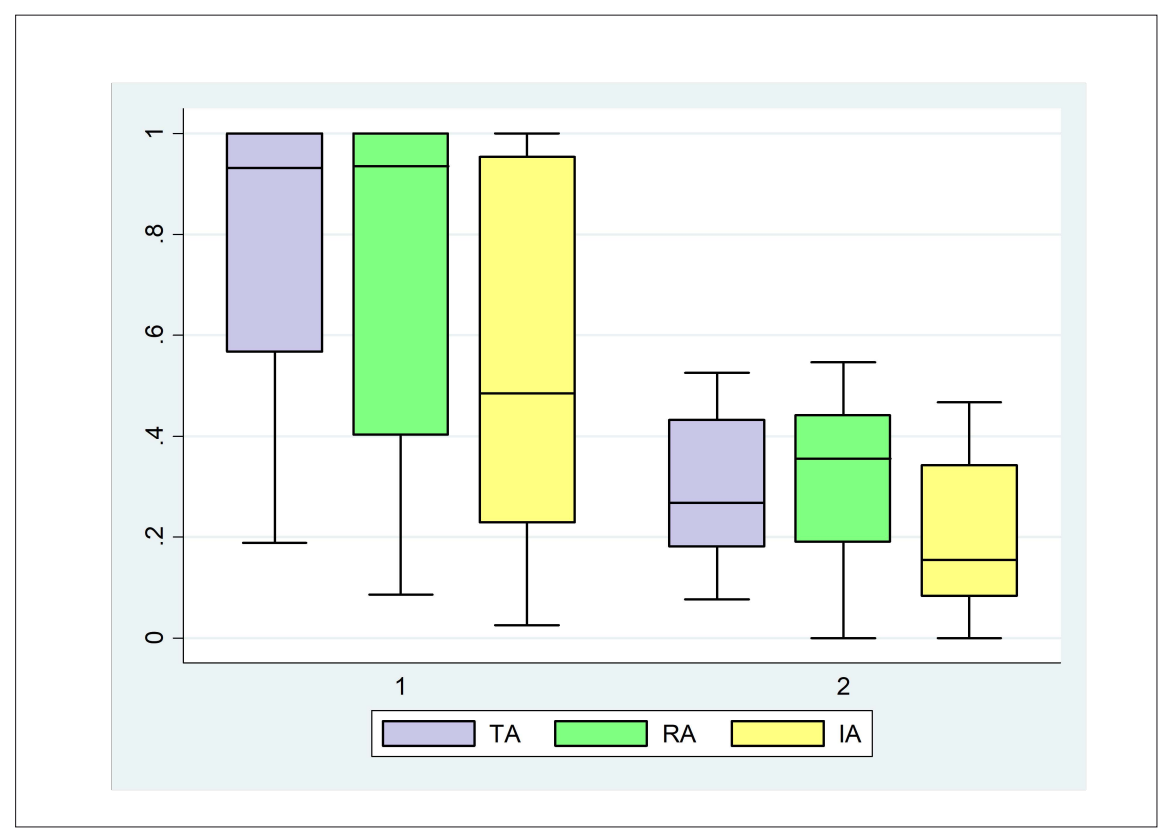

Figure 3: Box plot for TA, RA and IA for each cluster

Source: Author

After defining clusters in the second phase and statistical confirmation of the differences between them, the third phase can be approached, which will identify factors of impact for positioning within each cluster. 


\section{Journal of Contemporary Management Issues}

\subsection{THIRD STAGE: \\ IDENTIFYING KEY \\ FACTORS...}

In the third phase logistic regression is used to predict a probability of moving from one cluster to another in accordance with the change in independent variable. The model set in this phase of evaluation refers to the traditional static model of logistic regression where the dependent variable is dichotomous, i.e. has a value of 0 and 1 . A value of 1 is assigned to DMUs grouped into higherranked cluster 1 and the value 0 to DMUs grouped in the lower-ranked cluster 2. In this phase, factors that affect the results of relative efficiency of the first phase are determined. The software package Stata/IC 13.0 is used in the analysis. As logistic regression in this case assumes at least 28 parameters by variables (Peduzzi et al., 1996), and considering that the sample size is 31 , this set implies only univariate models.

The variables that are analysed are: "Public_Private_Cat" which provides information on the type of ownership, "PROPUB_Cat" - number of professional publications, "EXPACCSTUFF_Cat" - total expenditure per academic staff, "STUDperACCSTUFF_Cat" - the number of students per academic staff, "VISIT_Cat" - number of visiting lecturers and researchers, "ProfQ_Cat" - proportion of academic staff with the title of assistant professor, associate professor and full professor, "PROPROJ_Cat" - number of professional projects, "Competition_Cat" - number of HEIs of economic orientation in a certain area (county, region, canton) "GDPpc_Cat" - GDPpc in a certain area (county, region, canton), "SIZE_Cat" - size of the institution measured by the number of students enrolled in undergraduate and graduate studies, "SCPUB_Cat" - number of scientific publications, "SCPROJ_Cat" - number of scientific projects at the institution, "OR_in_TR_Cat" - share of own revenues in total revenues. All variables are dichotomous based on median value.

To define significant variables, first the Cramer's $\mathrm{V}$ is used as a measure of association. It is used to measure the power of association between a nominal variable with another nominal or ordinal variable. When Cramer's $\mathrm{V}$ has a value lower than 0.2 , it represents a weak effect. A preferred linkage is higher than 0.25 (University of Toronto, 2010). For variables EXPACCSTUFF_Cat, STUDperACCSTUFF_Cat and GUEST Cat it is a strong, very good connection while for variable Public_Private_Cat and PROPUB_Cat it is extremely strong.

Table 5: Power of association between dependent and independent variables - Cramer's V

\begin{tabular}{ll}
\hline Variables & Cramer's V \\
\hline Public_Private_Cat & 0.4364 \\
\hline PROPUB_Cat & 0.4961 \\
\hline EXPACCSTUFF_Cat & 0.3612 \\
\hline STUDperACCSTUFF_Cat & 0.3612 \\
\hline VISIT_Cat & 0.3612 \\
\hline ProfQ_Cat & 0.2263 \\
\hline PROPROJ_Cat & 0.2263 \\
\hline Competition_Cat & 0.1895 \\
\hline GDPpc_Cat & 0.1398 \\
\hline SIZE_Cat & 0.0914 \\
\hline SCPUB_Cat & 0.0914 \\
\hline SCPROJ_Cat & 0.0044 \\
\hline OR_in_TR_Cat & -0.0435 \\
\hline
\end{tabular}

Source: Author's calculations

Using Cramer's V information about association of independent variables with dependent variable (Cramer's $V>0.25$ ) is obtained. Hereinafter, using univariate binary logistic regression, association will be expressed as a power of prediction. 
Table 6: Results of univariate binary logistic regression

\begin{tabular}{llll}
\hline Variables & Odds ratio & 95\% Conf. Interval & p \\
\hline Public_Private_Cat & 4 & $1.337285-11.96454$ & 0.013 \\
\hline PROPUB_Cat & 7 & $1.590927-30.79966$ & 0.01 \\
\hline EXPACCSTUFF_Cat & 4.333332 & $1.234857-15.20643$ & 0.022 \\
\hline STUDperACCSTUFF_Cat & 4.333332 & $1.234857-15.20643$ & 0.022 \\
\hline VISIT_Cat & 4.333332 & $1.234857-15.20643$ & 0.022 \\
\hline
\end{tabular}

Source: Author's calculations

The odds ratio indicates that the odds for positioning in the higher-ranked cluster is significantly higher for public HEIs of economic orientation, for institutions that have published more professional papers, for institutions with higher total expenditures per scientific and teaching personnel, for institutions with higher number of students per scientific and teaching personnel and for institutions with more visiting lecturers and researchers. The results show that public HEIs have 4 times higher odds for grouping in the higher-ranked cluster than private HEIs of economic orientations. In addition, institutions crossing the median value of publication of professional papers (increase of PROPUB_Cat for one unit of measurement), have 7 times higher odds to position in cluster 1 . If the total expenditure by academic staff increases by one unit of measure, the institution has 4.33 higher odds to be part of cluster 1 . Institutions with larger numbers of students per academic staff are relatively more efficient and by increasing this variable for one unit, the institution has 4.33 times higher odds to qualify for the higher-ranked cluster 1. Likewise, institutions with higher numbers of visiting lecturers and scientists are relatively more efficient. The odds of positioning within cluster 1 is 4.33 times greater for institutions where the number of visiting lecturers and researchers increases by one unit of measure.

\subsection{Discussion}

It is assumed that the continuous application of the proposed evaluation model will have a large impact on increase in relative efficiency and, consequently, the quality of institutions. This would lead to many positive implications, both for institutions and for higher education and society in general. The institutions cognition on their position relative to their pears would allow them change towards more efficient activities. The effects of the proposed model are not reflected only at the level of individual institution and its benchmark, but can also serve as a guideline for design of educational policy as well as moderating the guidelines by the national authorities. The results indicate a better relative efficiency of public institutions compared to the private ones that is in line with research findings of Wilkinson and Yussof (2005) who concluded that public universities are more efficient than private ones in satisfying public demand in terms of quality of higher education provision. This result is logical and expected for several reasons. As stated in the issue of research, education is one of the strategic objectives of each nation's economy and as such is of public interest. Functions of institutions include the fulfilment of certain public goals: education of the population and increase in productivity through quality staff, publication of scientific and professional papers which should provide guidelines for economic and social 


\section{Journal of Contemporary Management Issues}

development, and connecting with foreign institutions with the aim of acquiring new knowledge and skills. Public HEIs are traditionally more oriented to achieve public goals, while private ones are more oriented to their financial sustainability. Therefore, it is reasonable to expect that the public HEIs achieve better results. Accordingly, from the aspect of ownership, results show a preference towards public HEIs of the economic orientation over the private ones. As the academic staff is most responsible for the implementation of the abovementioned objectives, their motivation and working conditions will significantly determine the achieved level of relative efficiency at their institution. Therefore, higher total expenditure per academic staff is an important prerequisite for achieving better results that is in line with research of Shin and Kehm (2013). It confirmed existence of a significant positive relationship between allocated budget resources per academic member and research outcomes. Since higher number of visiting lecturers and researchers has a positive effect on the results of relative efficiency, importance of investing in human resources is additionally emphasized. It is reflected through better networking and recognition of an institution and its academic staff. It can be assumed that better recognisability of institutions leads to a larger number of visiting lecturers and researchers. This finding is supported by research of Sidorenko and Gorbatova (2014) that observed efficiency of Russian universities through QS criteria. Since one of QS criteria is a number of foreign specialists on HEI, one of the main initiatives that they proposed is to increase the number of visiting professors to achieve their goal, i.e. to be ranked among 100 best universities according to World University Rankings. Recognisability of the institutions is not limited only in terms of international cooperation, but can be viewed in the context of economic activity. Therefore, connection between the results of relative efficiency and the number of professional publications provides information on the expertise and competence of the academic staff of HEIs within the economic community. This is in accordance with the findings of Sibel and Bursalioglu (2013) and Vink (1997) by which the number of publications has a positive effect on efficiency. In addition, the interest of students for the enrolment to a particular HEI is closely related to its recognisability and quality of implementation of its activities that are, among other things, manifested through the results of relative efficiency. Positive effect of number of students per academic on relative efficiency of universities is confirmed by Agasisti, Hippe and Munda (2017) and Sibel and Bursalioglu (2013). These results provide valuable information that are partly in opposition to certain policies for higher education that move in the direction of reducing employee benefits and funding of the institutions as well as reducing the number of students.

\section{CONCLUSIONS}

Quality assurance of HEIs is not possible without regular periodic evaluations of business processes. Therefore, it is necessary to use models which will provide quick and comprehensive information on the quality of the observed processes. This paper evaluates relative efficiency of 31 higher educational institutions of economic orientation in Croatia, Slovenia and Bosnia and Herzegovina through three phases. The basic assumption of this paper is that higher educational institutions are not equally efficient in every area of activity. Thereby, three main areas of their activities (teaching, research and international activity) are identified and their relative efficiency 
is evaluated. Based on the results of relative efficiency of different areas of activity, education institutions formed two clusters. Finally, key association factors of a particular cluster are identified and the probability of transition to a better ranked cluster is defined. Results show that the odds for positioning in the cluster with higher relative efficiencies scores are significantly higher for public HEIs, for institutions that have published more professional papers, for institutions with higher total expenditures per scientific and teaching personnel, for institutions with higher number of students per scientific and teaching personnel and for institutions with more visiting lecturers and researchers In recent years, the observed countries have started to make progress in terms of quality assurance in higher education. External audits and self-evaluations have a great importance in this process. However, there are some limitations of this study that should be addressed. When choosing inputs and outputs, some data was unavailable. Moreover, given the nature of HEIs, there are quality outputs that HEIs produce that are not measurable. Since data for some DMUs are partially aggregated, the estimation of financial parameters is carried out based on the number of students as a key of allocation (e.g. if certain financial data was available at the university or polytechnics level within which HEI of economic orientation operates). In addition, since the number of DMUs is limited, only univariate logistic regression could be carried out. Nevertheless, it is necessary to constantly make efforts and seek better solutions to contribute to this objective. The proposed empirical model complements the existing evaluation methods. Although applied to HEIs of economic orientation, it could be adapted to the needs of other HEIs with minor adjustments. Future research should be directed towards the calculation of the cut-off value i.e. the optimum value of total expenditure by academic staff, as well as the optimal number of students per academic staff in order to achieve greater levels of relative efficiency.

\section{REFERENCES}

1. Abbott, M. and Doucouliagos, C. (2003). The efficiency of Australian universities: a data envelopment analysis, Economics of Education Review, 22 (1), 89-97.

2. Agasisti, T. (2011). Performances and spending efficiency in higher education: a European comparison through non-parametric approaches. Education Economics, 19 (2), 199-224.

3. Agasisti, T., Hippe, R. and Munda, G. (2017). Efficiency of investment in compulsory education: empirical analyses in Europe, EUR 28607 EN. Luxembourg (Luxembourg): Publications Office of the European Union, JRC106678

4. Abd Aziz, N.A., Mohd Janor, R.M. and Mahadi, R. (2013). Comparative Departmental Efficiency Analysis within a University: A DEA Approach, Procedia - Social and Behavioral Sciences, 90 (10), 540-548.

5. Adler, N. and Yazhemsky, E. (n.d.) Improving discrimination in Data Envelopment Analysis: PCA-DEA versus Variable Reduction. Which method at what cost?, Hebrew University of Jerusalem, Working Paper of the Hebrew University Business School

6. Agency for science and higher education (2014). Number of students by fields of study for academic year 2008/09 to 2012/13, Retrieved 11/07, 2015, from: www.azvo.hr

7. Arbula, A. (2012). Using Data Envelopment Analysis to Evaluate 
the Efficiency of Higher Education Expenditure in Europe, Journal of International Scientific Publications: Economy \& Business. 6, 59-69.

8. Arbula Blecich, A. and Tomas Žiković, I. (2016). Evaluation of relative efficiency of higher education institutions of economic orientation, $5^{\text {th }}$ International Scientific Symposium „Economy of Eastern Croatia - Vision and Growth, Faculty of Economics, Osijek, Croatia, 2016. 368-376.

9. Arbula Blecich, A. and Zaninović, V. (2019). Insight into Students' Perception of Teaching: Case of Economic Higher Education Institution, Management: Journal of Contemporary Management Issues, 24 (1), 137-152.

10. Aristovnik, A. (2012). The relative efficiency of education and R\&D expenditures in the new EU member states, Journal of business economics and management, 13 (5), 832-848.

11. Aristovnik, A. and Obadić, A. (2011). The Funding and Efficiency of Higher Education in Croatia and Slovenia: A Non-Parametric Comparison, Amfiteatru Economic, 13 (30), 362-376.

12. Badri, M., Mohaidat, J. and El Mourad, T. (2014) Measuring the Efficiency of Public Schools using Data Envelopment Analysis - An Exploratory Study, Journal of Education and Practice, 5 (37), 215-232.

13. Beasley, J. E. (1990). Comparing university departments, Omega, 18 (2), 171-183.

14. Beasley, J. E. (1995). Determining teaching and research efficiencies, Journal of the Operational Research Society, 46 (4), 441-452.

15. Banker, R. D., Charnes, A. and Cooper, W.W. (1984). Some models for estimating technical and scale inefficiencies in data envelopment analysis, Management Science, 30 (9), 1078-1092.

16. Brovender, S. (1974). On the Economics of a University: Toward the Determination of Marginal Cost of Teaching Services, Journal of Political Economy, 82 (3), 657-664.

17. Cerović, Lj., Arbula Blecich A. and Štambuk, A. (2014). Relevant Areas and Indicators of Quality in Higher Education Institutions: Evaluating the System of Higher Education in Economics, Management: Journal of Contemporary Management Issues, 19 (2), 89-116.

18. Charnes, A, Cooper, W.W. and Rhodes, E (1978). Measuring the efficiency of decision making units, European Journal of Operational Research, 2 (6), 429-444.

19. Cohn, E., Rhine, S. L. W. and Santos, M.C. (1989). Institutions of Higher Education as Multi-product Firms: Economies of Scale and Scope, The Review of Economics \& Statistics, 71 (2), 284-290.

20. Ćukušić, M., Garača, Ž. and Jadrić, M. (2014). Odrednice i pokazatelji uspješnosti visokih učilišta u Hrvatskoj, Journal for General Social Issues, 23 (2), 233-257.

21. Dukić Samaržija, N., Arbula Blecich, A. and Najdek, T. (2018). Investigation of the Reimbursement Scheme in Croatian Public Hospitals: a Data Envelopment Analysis Approach, Economic and Social Development 28th International Scientific conference on Economic and Social Development, Paris, 358-366.

22. Gujarati, D.N. and Porter, D.C. (2009). Basic Econometrics, fifth edition, McGraw-Hill Higher Education, New York 
23. Institute for statistics of Federation of Bosnia and Herzegovina (20122014). Enrolled students and first year students at institutions of higher education, 2011/12-2013-14, Retrieved 17/12, 2013 from: www.fzs.ba

24. Jakir - Bajo, I. (2003). Mjerenje uspješnosti u hrvatskom javnom sekto$\mathrm{ru}$, Računovodstvo, revizija i financije, $8,37-41$.

25. James, E. (1978). Product Mix and Cost Disaggregation: A Reinterpretation of the Economics of Higher Education, Journal of Human Resources, 13 (2), 157-186.

26. Johnes, J. (2006). Data envelopment analysis and its application to the measurement of efficiency in higher education, Economics of Education Review, 25 (3), 273-288

27. Kaufman, L. and Rousseeuw, P. J. (1990, 2005). Finding Groups in Data. An Introduction to Cluster Analysis, John Wiley \& Sons, Inc., Hoboken, New Jersey

28. Khushalani, J. and Ozcan, Y.A. (2017). Are hospitals producing quality care efficiently? An analysis using Dynamic Network Data Envelopment Analysis (DEA), Socio-Economic Planning Sciences, 60, 15-23.

29. Kruss, G. and McGrath, S. (2015). Higher education and economic development: The importance of building technological capabilities, International Journal of Educational Development, 43 (July), 22-31.

30. Liu, C.-Y. A. and Tsai, C.-C. K. (2014). Evaluation on Higher Education Using Data Envelopment Analysis, International Journal of Management Excellence, 4 (2), 522-528

31. Mar Molinero, C. (1996). On the joint determination of efficiencies in a data envelopment analysis context, Journal of the Operational Research Society, 47 (10), 1273-1279.

32. McMillan, M. L. and Datta, D. (1998). The Relative Efficiencies of Canadian Universities: A DEA Perspective, Canadian Public Policy - Analyse de politiques, 24 (4), 485-511.

33. Ministry of science and education of the Republic of Croatia (2012). Strategic Plan for the period 2013.2015., Republic of Croatia, Retrieved 17/12, 2013, from: www.mzos.hr

34. Mooi, E. and Sarstedt, M. (2011). A Concise Guide to Market Research, Springer Berlin Heidelberg

35. Murias, P., de Miguel, J. C. and Rodríguez, D. (2008). A Composite Indicator for University Quality Assesment: The Case of Spanish Higher Education System, Social Indicators Research, 89 (1), 129-146.

36. Neamtu, D. M. (2015). Education, the economic development pillar, The 6th International Conference Edu World 2014 "Education Facing Contemporary World Issues", 7th - 9th November 2014, Procedia - Social and Behavioral Sciences 180, 413 - 420.

37. Peduzzi, P., Concato, J., Kemper E., Holford T.R. and Feinstein A.R. (1996). A simulation study of the number of events per variable in logistic regression analysis, $J$ Clin Epidemiol., 49 (12), 1373-1379.

38. Republic of Slovenia - statistical office - SI-STAT data portal (2012-2014). Students in tertiary education by fields of education, type of education, mode of study and academic year, Retrieved 7/10, 2016, from: www.stat.si

39. Robst, J. (2001). Cost Efficiency in Public Higher Education Institutions, The Journal of Higher Education, 72 (6), 730-750. 
40. Sagarra, Agasisti and Mar Molinero (2017). Exploring the Efficiency of Mexican Universities: Integrating Data Envelopment Analysis and Multidimensional Scaling, Omega, 67, 123-133.

41. Sarkis, J. (2002). Preparing Your Data for DEA, In N. Avkiran (Ed.) Productivity Analysis in the Service Sector with Data Envelopment Analysis ( $2^{\text {nd }}$ ed.) Academic press.

42. Sibel, S. and Bursalioglu, S. A. (2013). Analysis of the Determinants of Universities Efficiency in Turkey: Application of the Data Envelopment Analysis and Panel Tobit Model, 2nd Cyprus International Conference on Educational Research, (CYICER 2013), Procedia - Social and Behavioral Sciences, 89, 895 - 900.

43. Sîrbu, A., Cimpoieş, D. and Racul, A. (2016). Use of Data Envelopment Analysis to Measure the Performance Efficiency of Academic Departments, Agriculture and Agricultural Science Procedia, 10, 578-585.

44. Sidorenko, T. and Gorbatova, T. (2015). Efficiency of Russian education International Conference on Research Paradigms Transformation in Social Sciences 2014, Procedia - Social and Behavioral Sciences 166, 464 - 467.

45. Thanassoulis, E., Kortelainen, M., Johnes, G. and Johnes, J. (2011). Costs and Efficiency of Higher Education Institutions in England: A DEA Analysis, Journal of the Operational Research Society, 62 (7), 1282-1297.

46. Tierney, M. L. (1980). An estimate of departmental cost functions, Higher Education, 9 (4), 453-468.

47. Tsai, P. F. and Mar Molinero, C. (2002). A variable returns to scale data envelopment analysis model for the joint determination of efficiencies with an example of the UK health service, European Journal of Operational Research, 141 (1), 21-38.

48. Yang, Z. (2009). Bank Branch Operating Efficiency: A DEA Approach, Proceedings of the International Multi Conference of Engineers and Computer Scientists 2009 Vol II, IMECS 2009, March 18 20, 2009, Hong Kong

49. University of Toronto. (2010). Measures of association: Nominal data - phi and Cramer's V, Retrieved 10/03, 2015, from: http://homes.chass.utoronto.ca/ josephf/ pol242/LM-3A\#Measures\%20of $\% 20$ Association:\%20Phi\%20and $\% 20$ Cramers\%20V

50. Verry, D. W. and Layard, R. (1975). Costs functions for teaching and research, The Economic Journal, 85 (337), 55-74.

51. Vink, M.J.C. (1997). Efficiency in higher education: A comparative analysis on sectoral and institutional level. Twente, The Netherlands: Universiteit Twente.

52. Wilkinson, R., Yussof, I. (2005). Public and Private Provision of Higher Education in Malaysia: A Comparative Analysis. Higher Education, 50, 361-386.

53. Wolszczak-Derlacz, J. (2017). An evaluation and explanation of (in) efficiency in higher education institutions in Europe and the US with the application of two-stage semi-parametric DEA, Research Policy, 46 (9), 1595-1605.

54. Wolszczak-Derlacz, J. and Parteka, A. (2011). Efficiency of European public higher education institutions: a two-stage multi-country approach. Scientometrics, 89 (3), 887-917. 


\section{ČIMBENICI RELATIVNE EFIKASNOSTI VISOKOŠKOLSKIH USTANOVA IZ PODRUČJA EKONOMIJE}

Sažetak. U ovom se radu analiziraju čimbenici, koji utječu na relativnu efikasnost visokoškolskih institucija iz područja ekonomije. Empirijska je analiza provedena na 31 visokoškolskoj ustanovi u Hrvatskoj, Sloveniji te Bosni i Hercegovini, u tri faze. U prvoj je fazi evaluirana relativna učinkovitost promatranih ustanova za tri ključna područja, i to: nastavu, istraživanje te međunarodnu suradnju. U drugoj je fazi izvršena analiza klastera, na temelju rezultata relativne učinkovitosti za tri prethodno navedena područja aktivnosti. U posljednjoj-trećoj fazi, ključni čimbenici pripadnosti određenom klasteru utvrđeni su korištenjem univarijantne binarne logističke regresije te su određene vjerojatnosti za prijelaz u povoljniji klaster. Rezultati pokazuju da je vjerojatnost pozicioniranja u efikasnijem klasteru veća u javnim, negoli u privatnim institucijama, $u$ institucijama s više objavljenih stručnih radova, kao i onima s većim troškovima po nastavniku te $s$ većim brojem upisanih studenata po nastavniku, a na kraju - i onima s većim brojem gostujućih istraživača. Predloženi model može poslužiti kao vodič za kreiranje obrazovnih politika.

Ključne riječi: efikasnost, institucije visokog obrazovanja, analiza omeđivanja podataka, analiza klastera, logistička regresija 